\title{
Problems of Equivalence in Shona- English Bilingual Dictionaries
}

\author{
Nomalanga Mpofu, African Languages Research Institute, University of \\ Zimbabwe, Harare, Zimbabwe (nomalanm@yahoo.com)
}

\begin{abstract}
In compiling bilingual dictionaries, lexicographers are mostly concerned with semantic equivalence. As a result, the practice of bilingual dictionary compilers is usually that of giving one-word equivalents. However, this equivalence is at times difficult to arrive at because of the disparities and incommensurability between languages and cultures. According to Sapir (1921) and Whorf (1956), one cannot expect an exact match between two languages that express different cultural realities. Given this scenario, compilers of bilingual dictionaries end up bridging the gap between languages by giving translational equivalents rather than relying solely on one-word equivalents. The Shona-English bilingual dictionaries, namely Hannan (1974) and Dale (1981), like other bilingual dictionaries, also display this characteristic. This article will discuss the problems of translation equivalents in Shona-English dictionaries where lexicographers will be dealing with divergent languages and cultures, traditional practices of lexicography and the absence of reliable corpora.
\end{abstract}

Keywords: BILINGUAL LEXICOGRAPHY, CORPUS, CULTURE, CULTURE-BOUND, CULTURAL GAP, DICTIONARY, EQUIVALENCE, INCOMMENSURABILITY, LEXEME, LEXICOGRAPHY, SHONA, SOURCE LANGUAGE, TARGET LANGUAGE, TRANSLATION, UNTRANSLATABILITY

Opsomming: Ekwivalensieprobleme in Shona-Engelse tweetalige woordeboeke. By die opstel van tweetalige woordeboeke, is leksikograwe meesal bedag op semantiese ekwivalensie. Gevolglik is die gebruik by opstellers van tweetalige woordeboeke gewoonlik om enkelwoordekwivalente te gee. Soms is hierdie ekwivalensie egter moeilik om te bereik vanweë die ongelykheid en nieooreenstemming tussen tale en kulture. Volgens Sapir (1921) en Whorf (1956) kan 'n mens nie 'n presiese ooreenstemming verwag tussen twee tale wat verskillende kulturele werklikhede uitdruk nie. Gegee hierdie scenario, oorbrug die opstellers van tweetalige woordeboeke die gaping tussen tale uiteindelik deur vertalende ekwivalente aan te gee eerder as om uitsluitlik op enkelwoordekwivalente staat te maak. Die Shona-Engelse tweetalige woordeboeke, naamlik Hannan (1974) en Dale (1981), soos ander tweetalige woordeboeke, vertoon ook hierdie kenmerk. Hierdie artikel bespreek die probleme van vertalende ekwivalente in Shona-Engelse woordeboeke waar leksikograwe te doen het met uiteenlopende tale en kulture, tradisionele leksikografiese gebruike en die afwesigheid van betroubare korpusse.

Sleutelwoorde: BRONTAAL, EKWIVALENSIE, KORPUS, KULTURELE GAPING, KULTUUR, KULTUURGEBONDE, LEKSEEM, LEKSIKOGRAFIE, NIEOOREENSTEMMING, ONVERTAALBAARHEID, SJONA, TEIKENTAAL, TWEETALIGE LEKSIKOGRAFIE, VERTALING, WOORDEBOEK 


\section{Introduction}

The analysis of meaning is the basic activity in lexicography. The meaning of a lemma or expression is a concept related to the thing or idea that it refers to or that it represents which can be described with other words. In monolingual dictionaries, only one language is used for both the lemma and the glosses. On the other hand, in bilingual dictionaries, the meaning of a lexical item is derived through the process of translation of the source language (SL) word into that of the target language (TL). A bilingual dictionary, then, is one where two languages are used, one for the lemma and the other for the glosses. In the case of the Shona-English bilingual dictionaries, the lemmas are in Shona and the glosses in English.

According to Bassnett-McGuire (1988: 2), a minimally acceptable translation is one where the surface meanings of the SL and TL are approximately similar and also one that preserves the structures of the SL. In other words, the ideal in translation is to achieve structural and semantic equivalence. Absolute equivalence between any two languages, however, is rare. The reason for this is that one is dealing with languages with different structures and sociocultural settings. The semantic problems involved in bilingual dictionaries are more complicated than those in monolingual ones because the latter are written for people who participate in and understand the culture being described, whereas the former describe a culture which differs from that of the users (Al-Kasimi 1983: 58).

The major task of a bilingual lexicographer is to find appropriate equivalents (Al-Kasimi 1983: 58) but in some cases, the entries take the form of an explanatory or a descriptive equivalent. Such an equivalent is one which cannot be inserted into a sentence in the target language (Al-Kasimi 1983: 60). Explanatory or descriptive equivalents are necessitated by the absence of a translational equivalent in the target language. A translational equivalent is a lexical unit, which can be immediately inserted into a sentence in the target language (Al-Kasimi 1983: 60).

Much has been written on the problems of bilingual lexicography in other languages. Al-Kasimi (1983) discusses the problems of bilingual dictionaries from a linguistic point of view and with particular focus on English dictionaries. Landau (1984) and Zgusta (1971) concentrate on methods of dictionary making and general problems encountered in the process of compiling monolingual and bilingual dictionaries in English. Otani (1996) looks at the problems of equivalence in English-Japanese dictionaries with particular focus on content words, while Neubert (1990) writes on what one can expect a bilingual dictionary to achieve and for what, in fact, it should be consulted. His examples are drawn from German-English bilingual dictionaries. The problems these writers discuss, do not focus on the problems specific to Shona-English bilingual dictionaries, and this is the aim of this article.

The two best known bilingual Shona-English dictionaries are by Hannan, published in 1959 with a revised and expanded edition in 1974, and by Dale, 
published in 1981. Hannan and Dale were missionaries who compiled their dictionaries for evangelical purposes. Their choice of headwords seem to be of simple Shona words. Hannan's style of defining consists in giving equivalents for the main entries. Phrasal entries, such as idioms, are given as run-ons and are defined in the form of citations. Dale, on the other hand, first explains the main entries in Shona and then gives suitable explanations in English.

In Shona-English bilingual lexicography, there are instances where it is difficult to give exact equivalents, and this is where the lexicographer is left with little choice but to use explanations. The lexicographer, in trying to make his dictionary useful, will then resort to giving explanations, perhaps in the form of a paraphrase (Smit 1990: 30). These instances are: (1) lexical items with several designative functions, and (2) culture-bound words. The rest of this article will discuss these two topics.

\section{Problems of lexical items with several designative functions}

A word in a language may have more than one lexical function. A lexical function is the naming of the basic concept to which a word refers. According to Zgusta (1971: 27), a word can have several functions, one of which is the designative function. In Shona, certain lexical items have several designative functions which are not obvious to the dictionary user, and for which equivalents may be absent in the target language. A word's designative function is the thing or idea that it represents in the extralinguistic world. The other designative functions that a word may carry are sense extensions, which are usually figurative. A lexicographer, with the help of a comprehensive corpus, should be able to capture such senses so that the user is given the full range of meanings of any lexical item and their frequency of occurrence in the corpus.

The one problem of the existing Shona-English bilingual dictionaries seems to be the absence of a reliable corpus as well as the choice of literature the compilers thought relevant. Both Hannan and Dale used a corpus in the form of cards on which the words and the contexts were written. They extensively made use of biblical literature and Bible translations of which the language is now archaic. The corpus is therefore unbalanced and unreliable, and inaccurate in many respects, in comparison with an electronically processed corpus which is comprehensively and representatively built and in which frequency counts can be carried out. That is why, in Hannan for example, one finds unusual senses and word forms, such as hafubhaki (half-back), angere (angel) (instead of the familiar form ngirozi) and endekesi (a volume of the Bible, i.e. the Old or New Testament printed as one volume). Such uncommon forms would be met only once in an electronically processed corpus, and they would have been recognized as nonrepresentative of current usage, and might have been entered for historical interest only. The other problem has been that of reliance on traditional practices of lexicography. The relevant traditional prac- 
tices of dictionary making are: (1) giving no encyclopaedic information, and (2) focussing on structural and semantic equivalence.

The following examples refer to lexical items where the secondary designative functions are specific to Shona. The term -rara (sleep) can be used with sense extensions which refer to the outstanding characteristics of a slow or stupid person. Thus, a statement like Tendai akarara can mean that "Tendai is asleep", "Tendai is passive" or "Tendai is behaving foolishly". Both Hannan and Dale give the meaning of "being asleep". Because of the absence of a reliable source for all possible word senses for particular entries, neither of them gives the extended sense of the lemma, as is the case in Duramazwi ReChiShona (DRC) (Chimhundu (Ed.) 1996), a monolingual Shona dictionary compiled by mothertongue Shona speakers, who, however, used a corpus of about a million running words. In this dictionary, a second sense of -rara is given as Kana munhu akarara, anenge akapusa (If a person is asleep, it means that he/she is passive/foolish). According to DRC's definition, the term -pusa can also have several sense extensions other than that of being passive or foolish. It can also mean that the person is slow or stupid or that he/she is thickheaded and unable to think clearly, and further that something is easy or even light in weight. Dale just gives the sense of being passive or foolish, while Hannan gives the meaning of a thing or task being easy.

The word mai refers to one's own mother, but it is also used to address one's mother's sisters and one's uncles' (father's brothers') wives, and furthermore as a respectful term of address for any female who is assumed to be married. Dale gives the senses of "mother" and maiguru (mother's elder sister) and mainini (mother's younger sister), but does not give the sense of respect. Hannan gives the sense of "mother" and that of the title "Mrs". Both are correct, but their coverage is deficient in that Dale mentions the senses of maiguru and mainini but not that of "Mrs", while Hannan does not give the senses of maiguru and mainini.

The word mukadzi refers to a woman but it can also be used figuratively to refer to men in a negative way. Thus, if one says John mukadzi, it means that "John is a woman", but for John, being a man, such a statement would mean that John is either a coward or a good-for-nothing. The word mukadzi can also be used in a positive way to refer to a woman who is regarded as being good in everything she does. Thus, if one says Chenai mukadzi, one is saying that "Chenai is a woman", but what is actually meant is that Chenai is a good woman on whom one can always rely.

Similarly, the word murume refers to a man, but it is also used to refer to an economically independent woman who has managed to move into the domain usually occupied by men. The word can also be used to refer to a man who perseveres through hard times. If someone says John murume, it literally means that John is a man, but it can also mean that he is a man worth his salt. None of these sense extensions is incorporated in Hannan and Dale. The senses 
of mukadzi they include, are those of "woman" and "wife". For murume, they have the senses "man" and "husband".

Hannan's and Dale's omissions of some senses can be attributed to the lack of comprehensively and representatively built corpora for Shona and English. Reliable corpora would have given them examples of sentences where the extended senses of the words come out clearly. They may have relied solely on the intuitions of their mother-tongue Shona informants, but, even for mothertongue speakers, some senses only become distinctive when the different occurrences of a word in a corpus are studied. That is why, even for monolingual dictionaries, mother-tongue speakers rely heavily on corpora. For bilingual dictionaries, reliably built corpora for both languages are needed.

\section{Culture-bound words}

Language is at the core of culture and no culture can exist which does not have at its centre a natural language. A language thus reflects a specific culture, and languages are different because they reflect different cultures. As such, Shona has a wide range of terms that refer to traditional practices and artefacts and to cultural norms and rites. Because of this, there is a translation problem between Shona and English due to the cultural gap between the speakers of the source and target language. If the speakers of a certain language refer to a particular concept which does not exist in another language, it is almost impossible to translate it with a word or short phrase from that language. This problem where functionally relevant features in a source language do not exist in the target language (Smit 1990) can be referred to as cultural untranslatability. Culture, in this discussion, will be taken to mean whatever a person must know in order to function in a particular society (Wardhaugh 1998: 215). This knowledge is acquired socially. Two well-known linguists, Edward Sapir (1921) and Benjamin Lee Whorf (1956), wrote extensively on relationships existing between language and culture. Their findings came to be referred to as the Sapir-Whorf hypothesis which postulates that language and culture are inextricably related, so that one cannot understand or appreciate one without a knowledge of the other. According to this hypothesis, language cultures proceeding from different bases are fundamentally different from and incommensurable with each other (Hewson and Martin 1991: 25). This problem of the difference and incommensurability between two languages and cultures can be seen in any bilingual dictionary, particularly when it comes to terms that deal with culture.

The following illustrative examples will show some of the areas where the phenomenon of culture-bound words is frequent in Shona.

\section{(a) Traditional ceremonies and games}

The Shona have a number of traditional ceremonies to mark different events, mostly rites of passage. One such ceremony is that of kurova guva (the bringing 
home ceremony). This is a ceremony for bringing home the spirit of a person one year after his/her death. There is no equivalent term in English because such a ceremony does not exist in English culture. Hannan describes the ceremony as "the ceremony for uniting a mudzimu (ancestor) with his fellow spirit elders". Dale, on the other hand, defines it as "settle and incorporate spirit of dead person into the spirit world". Here, both Hannan and Dale concur that the ceremony has to do with a dead person's spirit. The point of deviation between them is that Dale gives the explanation in Shona first and then translates it into English:

-rova guva $t$ : -gadzira $t$. Kuchenura mweya womunhu akafa (nenhumbi dzawo) kuti ave mudzimu. vb settle and incorporate spirit of dead person (at kurova guva ceremony) into the spirit world.

Hannan's explanations of idioms such as -rova guva are usually run-ons under a main verb, in this particular example under -rova (strike, beat). They take the form of citations:

Hatiiti zvokurova guva kana mushakabvu aiva tsvimborume: we do not carry out the ceremony for uniting a mudzimu (ancestral spirit) with his spirit elders when the deceased was unmarried.

This citation does not explain what kurova guva is beyond observing that it is a "ceremony". All the user gets is a statement that makes no attempt to define the concept. What Hannan manages to bring out is the point that the ceremony is only held if the deceased was married. But this piece of information can only be useful to someone who knows what the ceremony of kurova guva involves. The ceremony is one that English speakers do not practice and that non-Shona speakers do not fully understand. The concept is "untranslatable" in the sense that it can be explained to an English speaker, but not in a word or phrase. It can only be done by a long definition that contains encyclopaedic information. Let us look at a possible definition when we do not have to rely on equivalents and are allowed to give encyclopaedic information:

-rova guva ceremony held after a year of a married person's death to bring home his/her spirit so that he/she may guide his/her family. (Bringing home ceremony). SEE ALSO mudzimu 3, -gara nhaka, sarapavana 1a/9.

One reason perhaps why bilingual lexicographers have not been free to give definitions that contain encyclopaedic information, is space constraints. According to Landau (1984: 137), the need to save space in dictionaries naturally leads to an injunction for brevity. But, at times, the need to save space produces definitions that fail to bring out the meaning of a word. Good bilingual dictionaries cannot always give brief definitions and still be useful. Cultural words can best be handled by giving encyclopaedic information. 
Like ceremonies, traditional games are often also culture-bound. An example is the game of nhodo. This is a game that girls usually play with pebbles, whereby a player will toss one into the air and before she catches it, she should have managed to pick up another one out of the hole. Both Hannan and Dale give the definition as "game similar to 'Jacks"'. The explanation serves to inform the user that it is a game close to the one he/she could be familiar with, but it is not an exact equivalent of that game. This is one of the words where a little encyclopaedic information would be useful. It would help users more if bilingual lexicographers explain the concept fully, in this case enough of how the game is played so that the user gets an idea of it. Only then will he/she be able to link it to the one he/she knows better.

\section{(b) Customs}

The Shona people observe many customs. Most of these customs pertain to rites of passage. One example is that of roora (lobola). Roora is the money and/ or cattle that a man pays to his in-laws as a way of seeking permission for him to live with their daughter as his wife. It can be loosely translated into English as "bride price". There is an extensive vocabulary in Shona for terms pertaining to this custom. There are no exact equivalents for most of these terms in English because the English have a different system of marriage.

One such term is pwanyaruzhowa. It is a nominal construction made up of the verb pwanya (break) and the noun ruzhowa (hedge). Literally it means that the man who will have come to marry one of the daughters, has actually broken the protective hedge around the homestead in order to gain entrance to her. The term refers to the money or a beast that the man has to pay for disturbing the peace of the homestead by wanting to take one of the daughters. Hannan defines it as "that one of the beasts of the danga (to do with cattle) part of roora that is not returnable in the case of divorce". While this piece of information may be important, what Hannan does not bring out is the purpose behind the paying of the beast in Shona culture.

The term matsvakirai kuno is another term that has no equivalent in English. It refers to the money that a man sends via his munyai (go-between) to the parents of the girl he has made to elope as a way of informing them that he is the one who has their daughter. Hannan defines it as "one of the impositions of the father-in-law". Hannan's definition lacks specificity and cultural content. In the roora custom, the father-in-law makes a lot of impositions that are regulated by the culture within which the custom is enshrined. With more information about these customs, Hannan would have been able to give more detail in his definitions.

While it may be acceptable for bilingual dictionaries to give explanations where there are no equivalents, these explanations have to be clear and helpful to the target users. The explanations given for the terms pwanyaruzhowa and matsvakirai kuno are not clear in existing bilingual Shona-English dictionaries 
and will not help either the Shona user who wants such terms explained well in English or the English user who wants to know the meanings of these Shona terms. When Shona speakers consult either Hannan or Dale, they find that their language and culture have not been properly described. Let us look again and see what a bilingual dictionary can be capable of achieving were it permitted to give encyclopaedic information for pwanyaruzhowa:

pwanyaruzhowa customary money or beast that is not returnable in the event of divorce, paid by the husband-to-be to his in-laws for disturbing the peace of the homestead by wanting to take one of their daughters.

\section{(c) Musical instruments}

What has been discussed of customs is also relevant for musical instruments. Some musical instruments are culture-bound. An instrument that is found among the Shona may not necessarily be found in other cultures and likewise, an instrument found in the English culture, may not be found among the Shona. The mbira is one instrument that is peculiar to Shona music. It is an instrument with many keys fixed to a board which is then fitted to a gourd that has been scraped so that it resonates well, and it is played with the fingers. The instrument has no English equivalent. Hannan describes it as a "small manykeyed musical instrument", while Dale gives the same definition, adding "Shona piano" as further explanation. In both these cases, the descriptions are imprecise because they focus on equivalence. As a consequence of cultureboundness, this equivalence is not possible.

The marimba is another instrument played by the Shona. This instrument is made of oblong blocks that are fitted onto a frame that has resonators such as gourds of different sizes attached underneath. The player beats the blocks with a padded stick and, depending on the size of the instrument, he/she can either sit or stand when playing it. Hannan describes it as a "many-keyed musical instrument with a resonator", while Dale just says that it is a "musical instrument". The hwamanda is defined by Hannan as a "horn (musical)", and by Dale as a "horn used as kind of bugle". It is, in fact, a horn, usually of a kudu, that is blown to accompany drums for dances.

Dale's and Hannan's explanations are correct, but they are not precise. Simply to say that an instrument is many-keyed presupposes that the user knows something about the instrument's make-up, shape, size and composition. Where there are no equivalents in the target language, as is the case here, then the explanations should be clear enough to create a precise image in the mind of the user. A suggested sample definition for hwamanda would be:

hwamanda musical instrument made out of animal horn, e.g. kudu, that is scraped and made hollow inside, and blown by the player to accompany drums for dances. 
All the examples discussed have no one-word equivalents in English, therefore the dictionary should describe or explain them.

\section{Conclusion}

The shortcomings of earlier Shona-English bilingual dictionaries are that glosses were made as brief and as short as possible. These bilingual dictionaries relied on the traditional norms of bilingual lexicography, that is, of giving equivalents and not adequate explanations or encyclopaedic information. However, more is needed, especially now that corpora have been developed. The use of a corpus would have yielded a better treatment of words. Pictures or sketches could also have been employed, as in Dale, to show the referents of some words in order to make the concepts clearer. Traditional lexicographic practices should be violated to produce a better product. As authoritative sources of reference and research, the bilingual dictionaries cited in this article fall short of their expectations because of the way they handle a variety of lexemes.

When users consult dictionaries, they will in most cases be looking up meanings. Examples such as those cited in this article, immediately show that the Shona-English bilingual dictionaries give inadequate explanations because of the lack of detail that characterizes these dictionaries. The users will thus fail to get the correct meaning of words and concepts found in a language, and, in turn, they will get limited information about that language from the available dictionaries.

These problems can be overcome by changing the general practice in bilingual Shona-English dictionaries of simply giving lexical equivalents, and, at least for some lexemes, shifting more in the direction of giving phrases or complete explanations with encyclopaedic information. There is also a need for electronically processed corpora to reveal extended senses so that, where necessary, the entry shows a wide variety of uses.

Hannan and Dale relied on what they thought were informed experts and a few books for headword selection and definitions. The absence of an electronically processed corpus can account for the lack of specificity in their definitions. With some of the cultural terms, a corpus would have been useful and they could have used it for adding encyclopaedic information as well as words for cross-referencing some of their entries.

\section{References}

Al-Kasimi, A.M. 1983. Linguistics and Bilingual Dictionaries. Leiden: E.J. Brill.

Bassnett-Mcguire, S. 1988. Translation Studies. London: Routledge.

Chimhundu, H. (Ed.). 1996. Duramazwi ReChiShona. Harare: The College Press.

Dale, D. 1981. Duramazwi: A Basic Shona-English Dictionary. Gweru: Mambo Press. 
Hannan, M. 1959. Standard Shona Dictionary. London: Macmillan

Hannan, M. 1974. Standard Shona Dictionary. Harare: The College Press.

Hewson, L. and J. Martin. 1991. Redefining Translation: The Variational Approach. London: Routledge.

Landau, S.I. 1984. Dictionaries: The Art and Craft of Lexicography. Cambridge: Cambridge University Press.

Neubert, A. 1990. Fact and Fiction in the Bilingual Dictionary. Euralex '90 Proceedings: 29-42. Barcelona: Biblograf.

Newmark, P. 1988. A Textbook of Translation. New York: Prentice Hall.

Otani, Y. 1996. Cross Language Equivalence: Between Lexical and Translation Equivalents in the Case of English-Japanese Dictionaries. Gellerstam, Martin et al. (Eds.). Euralex '96 Proceedings: 609-614. Göteborg: Göteborg University.

Sapir, E. 1921. Language: An Introduction to the Study of Speech. New York: Harcourt, Brace and Co.

Singleton, D. 2000. Language and the Lexicon. London: Arnold.

Smit, M. 1990. Translating Culture-bound Words: An Analysis in Terms of Semantic Voids. Unpublished M.A. Thesis. Stellenbosch: University of Stellenbosch.

Wardhaugh, R. 1998. An Introduction to Sociolinguistics. Oxford: Basil Blackwell.

Whorf, B.L. 1956. Language, Thought and Reality. Edited with an introduction by J.B. Carroll. Cambridge, Mass.: Massachusetts Institute of Technology / New York: John Wiley and Sons.

Zgusta, L. 1971. Manual of Lexicography. The Hague: Mouton. 